\title{
Entrepreneurship Education and Career Intentions of Tertiary Education Students in Akwa Ibom and Cross River States, Nigeria
}

\author{
Uduak Imo Ekpoh (corresponding author) \\ Department of Educational Administration and Planning \\ University Of Calabar, Calabar - Nigeria \\ Tel: 234-803-547-1469 E-mail: druduakekpoh@yahoo.com
}

Aniefiok Oswald Edet

Department of Educational Administration and Planning

University Of Calabar, Calabar - Nigeria

Tel: 234-803-724-7448_E-mail: draniefiokedet@yahoo.com

\begin{abstract}
This paper explores the impact of entrepreneurship education on career intentions among 500 students drawn from two universities in Akwa Ibom and Cross River States of Nigeria. The study adopted a survey design. Two research questions and two hypotheses were raised for the study. Data were collected using a structured questionnaire titled Entrepreneurship Education and Career Intentions Questionnaire (EECIQ). The data collected were analyzed using frequency counts, percentages and population t-test. Findings highlight that exposure to entrepreneurship education influences career intentions of tertiary school students.
\end{abstract}

Keywords: Entrepreneurship education, Career, Intentions, Tertiary students

\section{Introduction}

With the soaring unemployment rate in Nigeria, self employment and small enterprise initiatives are presently high on the country's national agenda, in the hope that they will provide alternative channels of employment. Yearly, thousand of university graduates join the labour market in search of gainful employment. The challenge is thus one of not only tackling the already sizeable unemployed graduates, but also of absorbing the new entrants into the labour market. Underlying this situation is the fact that the training which tertiary students receive has not been fully successful in equipping them with desirable skills and competencies required for job creation and self employment (Madumere-obike,2006, Amaewhule, 2007 and Nwangwu, 2007). The realization of this critical fact underlies the directive of the Federal Government to all tertiary education regulatory agencies to establish necessary mechanisms for the introduction, development and sustenance of entrepreneurial culture among Nigerian youths.

To make up for the curricula inadequacies in meeting employment problem, the National Universities Commission (NUC) in July, 2004, organized a workshop on entrepreneurship for Nigerian universities as a way forward. The NUC workshop produced a draft curriculum on entrepreneurial studies for Nigerian Universities. Consequently, many Universities have initiated entrepreneurship education programmes in an attempt to reverse graduate unemployment trend by giving the needed training in entrepreneurial skills to students for setting up businesses and to consider self employment as a viable career option.

Entrepreneurship education according to Isaac, Visser, Friedrick and Brijlal (2007) is the purposeful intervention by an educator in the life of the learner to survive in the world of business. It has as its focus an action orientation primarily embodied in teaching students how to develop a business plan (Ronstadt, 1985). Entrepreneurship education develops and stimulates entrepreneurial process, providing all tools necessary for starting up new ventures (Postigo and Tomborini 2002). It is commonly believed that entrepreneurship education is an imperative that would make a positive contribution to improving the entrepreneurship orientation of people, leading to the acquisition of skills, creativity, confidence, drive and courage, in order to create employment for self and others.

Entrepreneurship education has come to denote all forms of knowledge delivery that seek to empower the individual to create real wealth in the economic sector, thereby advancing the cause of development of the nation as a whole. According to Bassey and Archibong (2005), the goal of entrepreneurship education is intended to empower our graduates irrespective of their areas of specialization with skills that will enable them to engage in income yielding venture, if they are unable to secure jobs in the public sector. It is a reorientation from job seekers to job creators. 
The rationale for the inclusion of entrepreneurship curricula in universities according to Cotton, O'Gorman and Stampfi (2000) is that it will help graduates to acquire increased understanding of entrepreneurship, equip them with entrepreneurial approach to the world of work and prepare them to act as entrepreneurs and managers of new businesses. Thus, the objectives of entrepreneurship education as succinctly presented by the European Union (2002) include: "raising students' awareness of self employment as a career option (the message being that you can become not only an employee, but also an employer); promoting the development of personal qualities that are relevant to entrepreneurship, such as creativity, risk taking and responsibility; and providing the technical and business skills that are needed in order to start a new venture". From the foregoing it can be deduced that exposure of university students to entrepreneurial education will ginger- up entrepreneurial drive in students and if properly packaged, can be a significant factor in chronic unemployment reduction among graduates.

In Nigeria, entrepreneurship education is still at its infancy. While most Nigerian universities have initiated the programme, little research is available to assess its impact and also to confirm if a relationship exists between students taking courses in entrepreneurship and their intention of becoming entrepreneurs. In this context, it is of primary importance to understand whether entrepreneurship education raises career intentions to be entrepreneur generally or whether it helps students determine how well suited they are for entrepreneurship. This study therefore explores the impact of entrepreneurship education on career intention of tertiary education students.

\section{Literature review}

Previous research studies have shown that there is a significant relationship between entrepreneurship education and career intention. For example, a study by Kolvereid and Moen (1997) has shown that students with a major in entrepreneurship have a higher intention to engage as entrepreneurs and are likely to initiate business. Another study by Noel (2001) confirmed that students who graduated in entrepreneurship reached higher scores in entrepreneurial intention and entrepreneurial self-efficacy than students who graduated in other disciplines. Similarly, Varela and Jimenez (2001) study has shown that there is a correlation between a university's investment in the promotion of entrepreneurship and the percentage of students becoming entrepreneurs. Additional research by Autio, Keeley, Klofsten and Ulfstedt (1997) found that entrepreneurship education creates a positive image for the entrepreneurs and contributes to the choice of entrepreneurship as a professional alternative by graduates. Wilson, Kickul and Marlino (2007) found that, entrepreneurship education could also increase student's interest in entrepreneurship as a career.

Weihe and Reich (1993) conducted an international study of entrepreneurial interest among business student and found that $34.3 \%$ of those interviewed had an unreserved interest in self -employment. The study found the highest number of students already self-employed, 6\%, was in America. Similarly, Tkachev and Kolvereid (1999) findings showed that the self employment intentions among students could be increased through Entrepreneurship Training Programme (ETP). Scott and Twomey (1988), in their study, collected data from English students and reported that 25 percent had a business idea and 41 percent aspired to self employment.

A research that was conducted to a sample of 1000 MBA students from top business schools in USA showed that $44 \%$ responded that they wanted to become " an independent entrepreneur", while $34 \%$ wished to be "a high-ranking corporate manager" (Sandholtz, 1990). Also, Owusu-Ansah (2004) studied the impact of entrepreneurship education on career intentions and aspirations of tertiary students in Ghana and found that an overwhelming $77.9 \%$ of the survey respondents indicated they were motivated to a large or a very large extent to initiate business start-ups. Indication was also that $86.7 \%$ of the survey respondents felt equip with skills and competencies to initiate and run their own businesses.

Bassey and Olu (2008 ) investigated how students' perception of tertiary entrepreneurship education relate to graduate self employment potential in Nigeria using a sample of 690 students in three universities. The findings showed that there was a significant relationship between students' perception of University administration's provision for tertiary entrepreneurship education, curriculum objectives for tertiary entrepreneurship education, instructional methods for tertiary entrepreneurship education, quality and quantity of tertiary entrepreneurship education instructors and students' entrepreneurial traits and graduate self-employment potential.

The aim of this present study is to focus on the impact of entrepreneurship education on career intentions of tertiary education students.

\section{Statement of problem}

It has been realized previously that the type of education offered in most tertiary institutions produce graduates for whom there is no market demands. Graduates are produced for wage employment in the formal sector. Unemployment of graduates from Nigerian tertiary institution has become a major national problem. The period 
between graduation and employment dates has continued to lengthen and this has become a source of frustration for graduates. In the circumstance, it is obvious that the only viable option is self employment. Currently most universities have initiated entrepreneurship education programmes in the hope that it will equip university graduates with skills necessary to start their own businesses, to be job creators, instead of job seekers. This is sequel to the directives by Federal Government of Nigeria to all tertiary institutions, to offer entrepreneurship education courses so as to enhance the skills acquisition of tertiary education graduates for self employment. This paper therefore attempts to find out the impact of entrepreneurship education on career intentions of tertiary education students.

\section{Research questions}

Two research questions guided the study as follows:

(1) What are the career intentions of tertiary education students?

(2) What level of skills do students acquire after completing an entrepreneurship course?

\section{Hypotheses}

Two hypotheses were formulated to direct the study

(1) The benefits of entrepreneurship education is not significantly high.

(2) Students perceived barriers to starting a business venture is not significantly high.

\section{Methods}

The study was a descriptive survey design. A total of 500 students were drawn from two universities in Akwa Ibom and Cross River States of Nigeria. Final year students in the Departments of Economics, Business Administration, Accounting and Finance in 2008/2009 academic session were used for the study. These category of students were chosen because they are about to face their professional career choice and they belong to the highest entrepreneurial inclination segment of the population. To achieve the objective of the research, data were collected through a questionnaire titled Entrepreneurship Education and Career Intentions Questionnaire (EECIQ). The survey questionnaire had two sections. Section "A" examined career intentions and the skills acquired by students after acquiring entrepreneurship education. Students' career intention was measured by asking a question about their immediate career choice upon graduation. Categorical answers were listed as follows: Further studies; Self employment; Employment; Further studies and part-time business; Employment and part-time. Students were to tick the most applicable to their career choice. The level of skills acquired by students was grouped into 3; Low, Moderate and High. The students were asked to rate accordingly. Section "B" contained 20 item questions with a 4 point Likert - scale which ranged from Strongly Agree (4 points) to Strongly Disagree (1 point) to test the two hypotheses raised for the study. In section B, items 1-10 measured the students' perceived barriers to business start-up. The items generated included: lack of financial resources, lack of business management competence, how to explore business opportunities, lack of business ideas, lack of business advice, fear of failure, lack of information about business start-up and lack of marketing skills. Items 11-20 measured the benefits of entrepreneurship education. The items were creating awareness of business opportunities, developing creativity, building of self confidence, giving exposure to entrepreneurship process, developing resourcefulness, improving my planning skills, making me entrepreneur oriented, giving skills needed for self employment, giving motivation to start my own business and giving financial management skills. Two experts in Department of Educational Administration and Planning in University of Calabar carried out the face and content validation of the instrument. The reliability coefficient of the questionnaire by test-retest was 0.84 . The questionnaires were administered to all the sampled students by the researchers. Frequency counts, percentages and population t-test were the statistical techniques deployed to test the study hypotheses and also answer the research questions.

\section{Results}

\section{Research question 1}

What are the career intentions of tertiary education students?

The respondents were asked to indicate their career intentions after graduation. Results revealed that majority of the respondents 29.6\% (148) indicated employment, 26.8\% (134) indicated self employment, 21\% (105) employment and part time business, $15 \%$ (75) further studies, further studies and part time business $7.6 \%$ (38).Table 1 outlines the career intentions of students.

Quite revealing from this finding is the fact that $29.6 \%$ of the survey respondents indicated employment while $26.8 \%$ indicated self employment. Apparently $21 \%$ preferred joint career intentions. This result can be given several interpretations. In the first place, it appears that most undergraduates still prefer to be in the employment of others 
which is an indication of high preference for remunerative job. This corroborates the earlier findings of Onuma (2009) that most Nigerian graduates aimed for wage employment in the formal sector. Their social expectations are oriented to working and having a career in the management of private enterprises or for a career in the public sector. Also ( Ussman and Postigo, 2000 ) in Postigo and Tamborini ( 2002), reported that, the academic programmes of most universities have a tendency to focus the education of their students toward a professional career as employees and rarely consider the opportunity of developing competences that will allow alumni to start their own projects.

The fact that $26 \%$ had intention of starting their business is an indication that entrepreneurship education has created a positive impact on the respondent to consider self employment as a career option. This finding affirms Autio et al (1997) research that entrepreneurship education created a positive image for entrepreneurship as a career. It also corroborates Fayolle (2005) view that entrepreneurship courses create more entrepreneurship students which in turn lead ultimately to a greater number of students willing to start their own businesses. This finding also agrees with that of Kolvereid and Moen (1997) that graduates with entrepreneurship major were more likely to start new businesses and had stronger entrepreneurial intention than other graduates.

A major revealing finding of this study is the desire of the respondents to have a joint career intention of entering into employment and running a business on part-time basis. This finding suggests the reluctance of the respondents to take risk. A plausible explanation is the apparent strategy of generating funds to finance the part time business. This articulation is in consonance with Owusa-Ansa (2004), who noted that combining employment and part-time business is a risk diversification strategy of generating capital to finance the business start-up. Finance is a major barrier to business start - up in Nigeria. A joint career intention would probably provide the necessary finances for business start- up and will serve as a back- up.

\section{Research question 2}

What level of skills do students acquire after completing an entrepreneurship course?

The students in this study were asked to rate the level of skills acquired after undertaking entrepreneurship education. The level of skills was grouped into three, low, moderate and high. Clearly, a significant proportion of the participants indicated moderate skills 236 (47.2\%); 144 (28.8\%) high skills and 120 (24\%) low skills (see Table 2). The result of this study upholds the previous findings of Thandi and Sharma (2004) that, entrepreneurship courses can indeed raise the level of students' skills on entrepreneurial activity. Equally, these findings support the arguments of Garavan and O'Cinnede (1994) that, education or training can influence the development of entrepreneurial role. Evidently, the result of this study is an indication that entrepreneurship education has, to a certain extent, created a positive impact on the respondents and has raised their level of skills. This finding is instructive against the background that entrepreneurship education in Akwa Ibom and Cross River institutions is relatively recent and merely taught for a semester on an ad hoc basis. Besides, most of the lecturers who teach the course are not experts. Moderate skill is also an indication that much of what is done is theoretical with little or no exposure to practical aspect. This could however be due to lack of facilities.

\section{Hypothesis 1}

The benefit of entrepreneurship education to student is not significantly high.

This hypothesis is a one variable hypothesis. The test statistic used in analyzing data relevant to it was population t-test for one sampled study. In carrying out the test the researchers first determined the population mean $(\mu)$ using the 4 point scale. The scale spanned from strongly agree (4points) to strongly disagree (1point). Thereafter, all the points on the scale were added up. The results were then aggregated for the ten items measuring the variable to give $25.0(2.5 \times 10=25.0)$. With this, the sample mean $(\mathrm{x})$ was compared with the population mean $(\mu)$ to obtain the $\mathrm{t}$-value. The results are presented in Table 3 .

The results in Table 3 indicate that the calculated t-value of 30.314 is greater than the critical t-value of 1.65 at 0.05 level of significance with 499 degrees of freedom. This means that the benefit of entrepreneurship education to students is significantly high. By this result the null hypothesis is rejected.

This findings corroborates the previous research findings of Kolvereid and Moen (1997), Owusu-Ansah (2004) and Cotton et al (2000) that entrepreneurship education helps graduates to acquire increased understanding of entrepreneurship and equip them with skills relevant for job creation.

A deduction from these findings is that the benefits of entrepreneurship education are significantly high. The study evidence shows that entrepreneurship education creates inspiring awareness to business opportunity, provides exposure to entrepreneurship process, builds self confidence, equip students with knowledge and skills and engender self employment as a career option. 


\section{Hypothesis 2}

Students' perceived barriers to starting a business venture is not significantly high.

The test statistic used in analyzing data relevant to this hypothesis was population t-test for one sample mean. The results of the analysis are presented in Table 4.

Results in Table 4 shows that the calculated t-value of 6.443 is greater than the critical t-value of 1.65 at 0.05 level of significance with 499 degrees of freedom. This means that students' perceived barriers to business start up is significantly high. The null hypothesis is rejected.

From the findings, it is obvious that a number of obstacles do however militate against starting a business venture. High among these being lack of access to starting capital and lack of business ideas. This finding upholds the research previously reported by Owusu-Ansah (2004) that many students and graduates perceive several obstacles that relatively affect the outcomes of entrepreneurship programmes. Among the perceived factors include gaining access to finance, lack of business management skills, lack of experience and ideas. In addition there is the added burden of lack of a credit history that thwart efforts at getting credit from the banking system.

\section{Conclusion}

The findings of this study show that entrepreneurship education impacts positively on the career intentions of tertiary education students. As it is shown in this study, entrepreneurship education leads to increase in the level of students knowledge in entrepreneurial process. The present initiative by the National University Commission (NUC) in integrating entrepreneurship education into the formal University curriculum is making significant contribution in encouraging a positive orientation among University undergraduates. It is hoped that this initiative will bridge the gap and change the mindset of tertiary education graduates from job seekers to job creators.

\section{Recommendations}

Based on the findings of this study, the following recommendations are made:

- The duration and intensity of the entrepreneurship education should be increased beyond a semester's course to realize a maximum impact on university students.

- Entrepreneurship education should not only be offered at the university level but should be entrenched and made compulsory at all other levels of education.

- Access to finance by micro, small and medium enterprises must be well liberalized by the government. There should be unhindered access to micro-credit for young graduates.

- Entrepreneurship education should be practical oriented so as to sustain students interest.

\section{References}

Amaewhule, W. A. (2007). Education, the world of work and the challenge of change: In search of intervention strategies. Inaugural lecture series No. 23; River State University of Science and Technology, Nkpolu Port Harcourt.

Autio, E., Keeley, R, Klofsten, M. \& Ulfstedt, T. (1997). Entrepreneurial Intent among Students: Testing an intent model in Asia, Scandinavia and in USA. Frontiers of Entrepreneurship Research, Babson conference proceeding,.

Bassey, U. U. \& Archibong, I. A. (2005). Assuring quality graduate output through entrepreneurial oriented education in Nigerian universities. Nigerian Journal of Curriculum Studies, 12(3),18-23.

Bassey, U. U. \& Olu D. (2008). Tertiary Education and Graduate Self-Employment Potentials in Nigeria. Journal of the World Universities Forum, 1(3), 131 - 42.

Cotton, J., O'Gorman, C. \& Stampfi, C.(2002). Can national education policies meet the call for more entrepreneur? A project supported by the European community (Project Number - FIN/00/C/P/RF/92650) (www.google.com); March, 2005.

European Union. ( 2002). Final report of the expert group "Best procedure" project on Education and Training for Entrepreneurship. Brussels: European Commission Directorate - General for Enterprise.

Fayolle, A. (2005). Evaluation of Entrepreneurship Education: behaviour performing or intention increasing. International Journal of Entrepreneurship and Small Business, 1(2) 1, 89 - 98.

Garavan, T. N. \&s O'Cinneide, B. (1994). Entrepreneurship education and training programmes: a review and evaluation, Journal of European Training, 18(8), 3 - 12. 
Isaacs, E., Visser, K., J Friedrich C. \& Brijlal, P. (2007). Entrepreneurship education and training at the further education and training (FET) level in South Africa. South African Journal of Education, 27, 613 - 629.

Kolvereid, L. \& Moen, O. (1997). Entrepreneurship among business graduates: Does a major in entrepreneurship make a difference? Journal of European Industrial Training, 21 (4), 154.

Madumere-Obike, C. U. (2000). Reposition Education for Employment: Implications for educational management. Multidisciplinary Journal of Research Development (MIKJORED); 7(3) 43-52.

Noel, T.W. (2001). Effects of entrepreneurial education on student to open a business. Frontiers of Entrepreneurship Research, Babson, Conference Proceedings. Babson College.

Nwangwu I. O. (2007). Entrepreneurship in education. Concept and constraints. African Journal of Education and Developmental Studies 4(1), 196 - 207.

Onuma, N. (2009). Rationale for youth preparation and entrepreneurship education in the face of global economic crisis in Nigeria. Annals of Modern Education, 1(1), 224-232.

Owusu - Ansah, W. A. (2004). The impact of entrepreneurship education on career intentions and aspiration of tertiary students in Ghana. A paper presented at the 49th World Conference of International Council for Small Business, 20th to 23rd June 2004, Johannesburg, South Africa.

Postigo, S. \& Tamborini, M. F. (2002). Entrepreneurship education in Argentina: The case of San Andres University. Paper Presented for Internationalizing Entrepreneurship Education and Training Conference (INTENT 2002), Malaysia, July 8 - 10.

Ronstadt, R. (1985). The Educated entrepreneurs: A new era of entrepreneurial education is beginning. American Journal of Small Business. 10 , 7 - 23.

Thandi, H. \& Sharma, R. (2004). MBA students preparedness for entrepreneurial efforts. Tertiary Education and Management. (10), 209 - 226.

Tkachev, A. \& Kolvereid, L. (1999). Self employment intentions among Russian students. Entrepreneurship and Regional Development, 11(3), 269-280.

Scott, M. F. \& Twomey, D. F (1988). The long term supply of entrepreneurs: students career aspirations in relation to entrepreneurship. Journal of Small Business Management, 26(4) 5 - 14.

Sandholtz, K. (1990). MBA attitudes, The College Edition of the National Business Employment Weekly, spring.

Varela, R. \& Jimenez, J. E. (2001). The effect of entrepreneurship education in the Universities of Cali. Frontiers of entrepreneurship research, Babson Conference proceedings.

Wilson, F., Kickul, J. \& Marlino, D (2007). Gender, entrepreneurial self-efficacy, and entrepreneurial career intentions: Implication of entrepreneurship education, Entrepreneurship: Theory and practice 406.

Weihe, H. J. \& Reich, F. R. (1993). Entrepreneurial interest among business students: Results of an international Study. In H. A. Klant (Ed.) Entrepreneurship and Business Development.

Table 1. Career intention of tertiary education students after graduation.

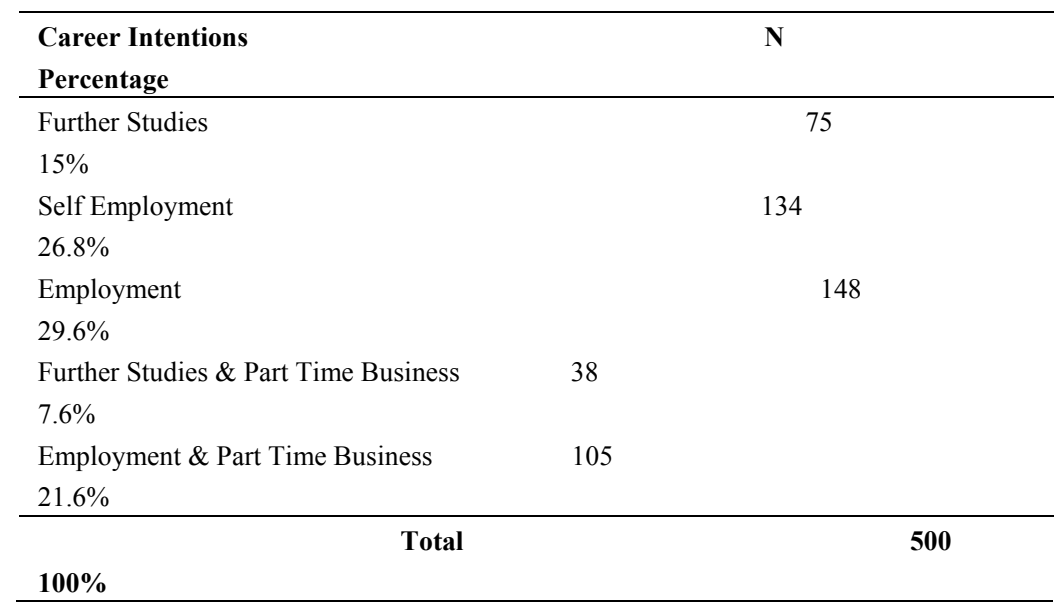


Table 2. Level of skills acquired to start a business

\begin{tabular}{lc}
\hline $\begin{array}{l}\text { Response } \\
\text { Percentage }\end{array}$ & Frequency \\
\hline High Skills & 144 \\
$28.8 \%$ & 236 \\
Moderate Skills & \\
$47.2 \%$ & 120 \\
Low Skills & \\
$24 \%$ & 500 \\
$100 \%$ & \\
\hline
\end{tabular}

Table 3. Population t-test of the benefit of Entrepreneurship Education (E.E)

\begin{tabular}{|c|c|c|c|c|c|c|}
\hline Variable & $\mathbf{n}$ & $\bar{x}$ & $\mu$ & & SD & $\mathbf{t}$ \\
\hline Benefit of E. E & 500 & 31.90 & - & & 5.09 & $30.314 *$ \\
\hline Reference score & - & ـ & & 25.0 & & \\
\hline
\end{tabular}

*significant at $.05, \mathrm{df}=499$ critical $\mathrm{t}=1.65$

Table 4. Population t-test of the perceived barriers to business start-up by students

\begin{tabular}{|c|c|c|c|c|c|}
\hline Variable & $\mathbf{n}$ & $\bar{x}$ & $\mu$ & SD & $\mathbf{t}$ \\
\hline Perceived Barriers & 500 & 26.93 & 6.68 & $6.443 *$ & \\
\hline Reference score & & & - & 25.0 & - \\
\hline
\end{tabular}

$*$ significant at $.05, \mathrm{df}=499$ critical $\mathrm{t}=1.65$ 